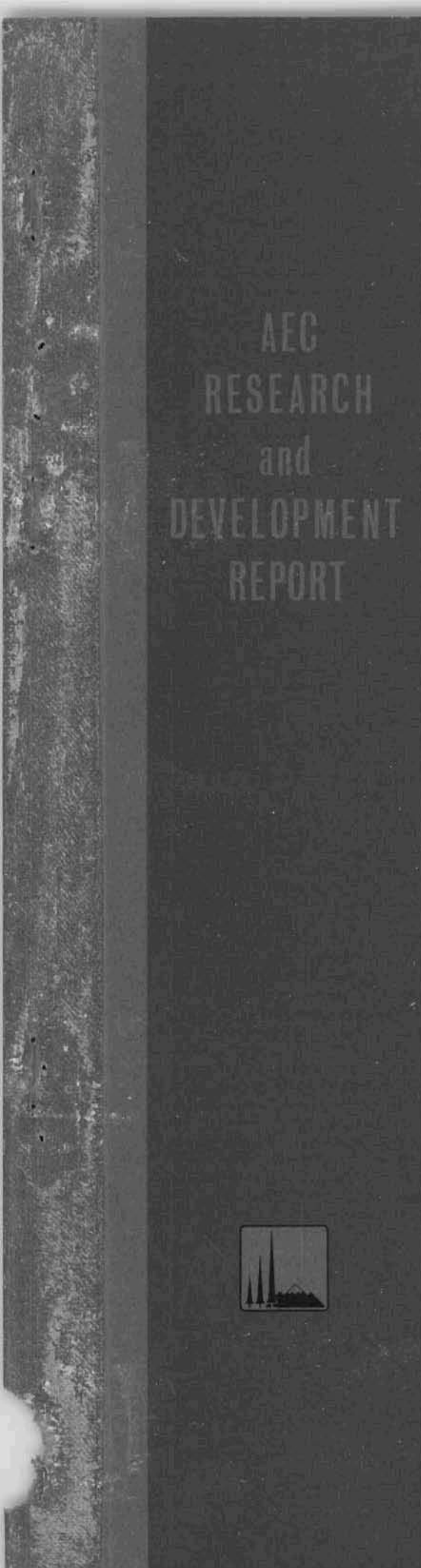

\title{
SLIP CASTING OF RARE EARTH OXIDES
}

\author{
BY \\ H. T. FULLAM \\ CHEMICAL RESEARCH SECTION \\ CHEMISTRY DEPARTMENT
}

JUNE 1967

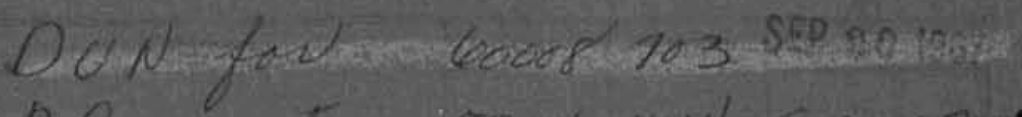

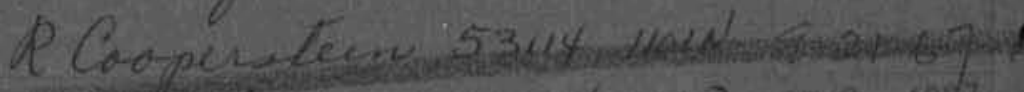
D. ON ful 600087030078 isit

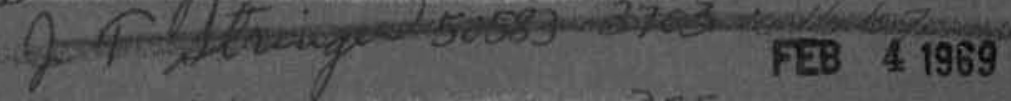
A. contseres

\section{EATTELLE $=\sqrt{\text { ORTHMEST }}$}

BATTELLE MEMORIAL INSTITUTE / PACIFIC NORTHWEST LABORATORY 


\section{LEGAL NOTICE}

This report was prepared as an occount of Government sponsored work. Neither the United States, nor the Commission, nor any person acting on behalf of the Commistion

A. Makes any warranty or representation, expressed or implied, with respect to the accuracy, completeness, or usefulness of the information contained in this report, or that the use of any information, opparafus, method, or process disclosed in this report may not infringe privately owned rights; or

B. Assumes any liabilities with respect to the use of, or for damages resulfing from the use of any information, apparatus, method, or process disclosed in this report.

As used in the above, "person acting on beholf of the Commission" includes any employee or contractor of the Commission, or employee of such contractor, to the extent that such employee or contractor of the Commission, or employee of such contractor prepares, disseminates, or provides access to, any information pursuant to his employment or controct with the Commission, or his employment with such contractor.

\section{PACIFIC NORTHWEST LABORATORY \\ RICHLAND, WASHINGTON \\ operated by \\ BATTELLE MEMORIAL-INSHTUTE}

for the

UNITED STATES ATOMIC ENERGY COMMISSION UNDER CONTRACT AT(45-1)-1830 
BNWL-437

UC-25, Metials, Ceramios and Materials

SLIP CASTING OF RARE EARTH OXIDES

By

H. T。Fullam

Chemical Research Section

Chemistry Department

June, 1967

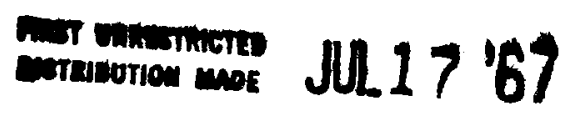

PACIFIC NORTHWEST LABORATORY

RICHLAND, WASHINGTON 
Printed in the United States of America Available from

Clearinghouse for Federal Scientific and Technical Information National Bureau of Standards, U.S. Department of Commeree

Springfield, Virginia 22151

Price: Printed Copy $\$ 3.00$, Mierofiche $\$ 0.65$ 


\section{TABLE OF CONTENTS}

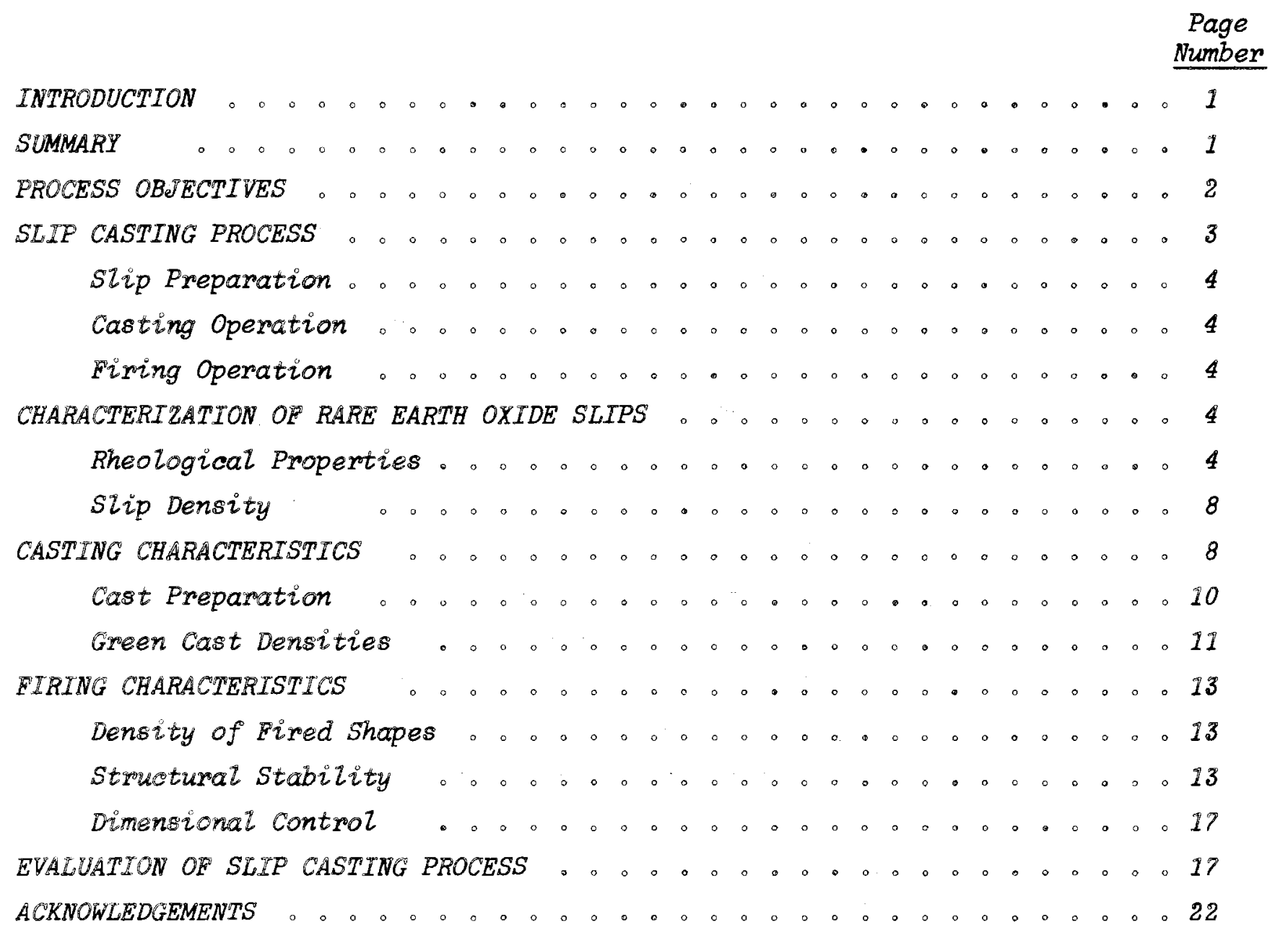




\section{SLIP OASTING OH RARE OXTDES}

\section{INTROOUCTYON}

As part of the promethium development program at the Pacific Northwest Laboratory (Battelie-Northwest) yarious methods of compacting promethium sesquioxide into useful shapes of high density have been evaluated. Fabrication techniques scouted include. cold pressing and sintering (i), hot pressing, (2) slip casting, fusion casting, and pneumatic impaction. This report sumarizes a very brief study on the use of silp casting as compaction method.

Since the avaliability of promethium sesquioxide was limited and because large amounts of oxide were required in the slip casting studies, the sesquioxides of samarium and neodymium were used as standins for $\mathrm{Pm}_{2} \mathrm{O}_{3}$ in this work. The results of other compaction studies (2) have shown that data obtained with $\mathrm{Sm}_{2} \mathrm{O}_{3}$ and $\mathrm{Na}_{2} \mathrm{O}_{3}$ are generally applicable to $\mathrm{Pm}_{2} \mathrm{O}_{3}$. It is felt, therefore, that the sip casting results obtained with standins are applicable to piromethium sesquioxide.

Time available for this work was limited and it was impossible to study all the variables inyolwed in slip casting the rare earth oxides. The work was carried only to the point where an evaluation or its potential coula be made. For this reason many of the observations and conclusions stated are qualitative in nature rather than quantitative.

\section{SUMMARY}

The sesquioxides of samarium and neodymium can be slip cast (solid casting) in plaster molds very readily. Slip preparation is simple and under optimum conditions the cast shape is easily removed from the mold. Green cast shapes having densities greater than $5 \mathrm{gm} / \mathrm{co}$ were prepared using $\mathrm{Sm}_{2} \mathrm{O}_{3}$ The only major problem encountered was the tendency of the cast shape to crack on firing. Green shapes of low initial density always cracked or spalled bady

$I_{H}, T . F u l l a m$ and $L_{0} J_{0}$ Kirby, Cold Pressing and Sintering of Rare Earth Oxides, BNWL-386, May, 2967.

${ }^{2} H_{0}$ T. Fulzam, Hot Pressing of Rare Earth Oxides, BNWL-448, June $296 \%$ 
on firing. The problem was not as serere with green shapes of high density, and by using very slow heating and cooling rates, it was possible to produce fired shapes that were essentially free of flaws.

By firing the green cast shapes at temperatures of $1500^{\circ} \mathrm{C}$ and higher, it was possible to produce $\mathrm{Sm}_{2} \mathrm{O}_{3}$ bodies having densities in excess of 7.2 $\mathrm{gm} / \mathrm{co}$ (theoretical density is $7.74 \mathrm{gm} / \mathrm{so}$ ). Very little sintering and compaction occured when the shapes fired at temperatures below $1200^{\circ} \mathrm{C}$. Green shapes of high initial density showed relatively even shrinkage and little distortion on firing. Low-density green shapes, however, showed very irregular shrinkage or firing in adation to cracking.

The over-all potential of silp casting as a method for fabricating promethium sesquioxide into usefui shapes depends primarily on the dimensional control required. In those cases where a high degree of dimensional control is required, slip casting does not appear to be practical since dimensional variations of $2-3 \%$ often rewult on firing the cast shapes. If some dimensional variations can be accomodated, howerer, slip casting appears to be a suitable method for producing $\mathrm{Pnn}_{2} \mathrm{O}_{3}$ shapes of moderateiy high density (90-95\% of theoreticaly.

Because of radiation exposure probiems, any large-scale repetitive production operation would have to be carried out in a remotely operated facility。A limited number of casts could be prepared in a gloved box, however, without excessive operator exposure.

\section{PROCESS OBJECTIVES}

In fabricating promethium sesquioxide into useful shapes, there are three basic objectives which the fabrication process should meet:

- The final oxide shape should have a high density and the density should be uniform。 
The final fired shape should have good physical strength.

Dimensional control of the shape should be good so that source encapsulation is simpified.

in addition there are certain operational requirements which the process should fulfill:

Physical operations of the process should be simple so they can be easily carried out in a remotely operated facility (such as a hot cell) or a shielded glove box.

If the work is done in a shielded glove box, the operations should be such that handi.ing requirements are small and operator exposure reduced to a minimum。

- Physical containment of the oxide within the box should be good so that background radiation levels in the glove box are low and box cleanup times reduced to a minimum.

Over-all evaluation of the slip casting process as a means of compacting promethium sesquioxide into useful shapes will be based on all of the above requirements.

\section{SLIP CASTING PROCESS}

Slip casting of rare earth oxides can be carried out using standard ceramic techniques (in this work, slip casting refers to solid casting as pposed to drain casting). The process breaks down into three basic operations:

Preparation of the aqueous slip.

Casting of the slip in a plaster mold.

Firing of the cast shape.

Each of the three steps as they apply to the slip casting of samarium and neodymium sesquioxides are discussed briefly in the following sections. 


\section{Siip Preparation}

Aqueous slips of rare earth oxides are prepared by combining a weighed amount of oxide with a deflocoulating agent, adaing a known volume of water, and mixing the resulting slurry until a filuid slip is obtained. The defiocculating agent used in this work was Daxad 23, supplied by Dr。R。S. Rosenfels of Isochem, Ine. Milling of the silp is caried out in a porcelain ball mill using alumina balls. Normally about one hour's miliing produces a siip of minimum wiscosity.

\section{Casting Operation}

After the slip is milled, it is removed from the bali mill and poured into a plaster-of-paris mold. As water is adsorbed by the mold additional slip is added until the mold is filled. Once the mold is filled, it is allowed to set until the adsorption of water is complete and the cast shape is firm. The cast shape is then removed from the mold and its physical dimensions and weight determined. It normaliy takes 30-60 minutes for the cast to set up to the point where it can be removed from the mold. All of the shapes cast in this work were right eireuiar oylinders.

\section{Firing}

The green east shape when removed from the mold normally contains about 10\% water. Most of this water is removed by arying the cast in a flowing stream of air at ambient temperature. The air-dried shape (containing $\left.0.5-i_{0} 0 \% \mathrm{H}_{2} \mathrm{O}\right)$ is then heated to approximately $80^{\circ} \mathrm{C}$ and heid for one hour. The temperature is then slowy increased to the final firing temperature. A typical firing curve

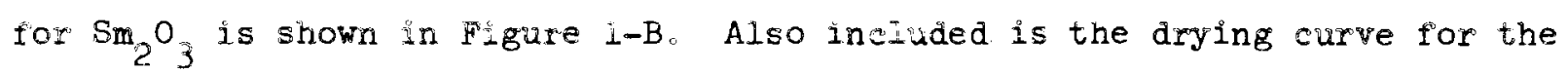
cast shape $(1-A)$.

\section{CHARACTERIZATION OF RARE EARTH OXIDE SLIPS}

Samarium and neodymium slips can be prepared very readily. The fluidity of the silp dewas on its water content and miling time. A defloceulating agent is required to reduce slip viscosity to a useable level.

\section{Rheological Properties}

From an operational viewpoint, the viscosity of the slip is the most important variabie to be considered. In this work slip viscosities were measured with a Brookfield Model RVT viscometer. It was difficult to get an 

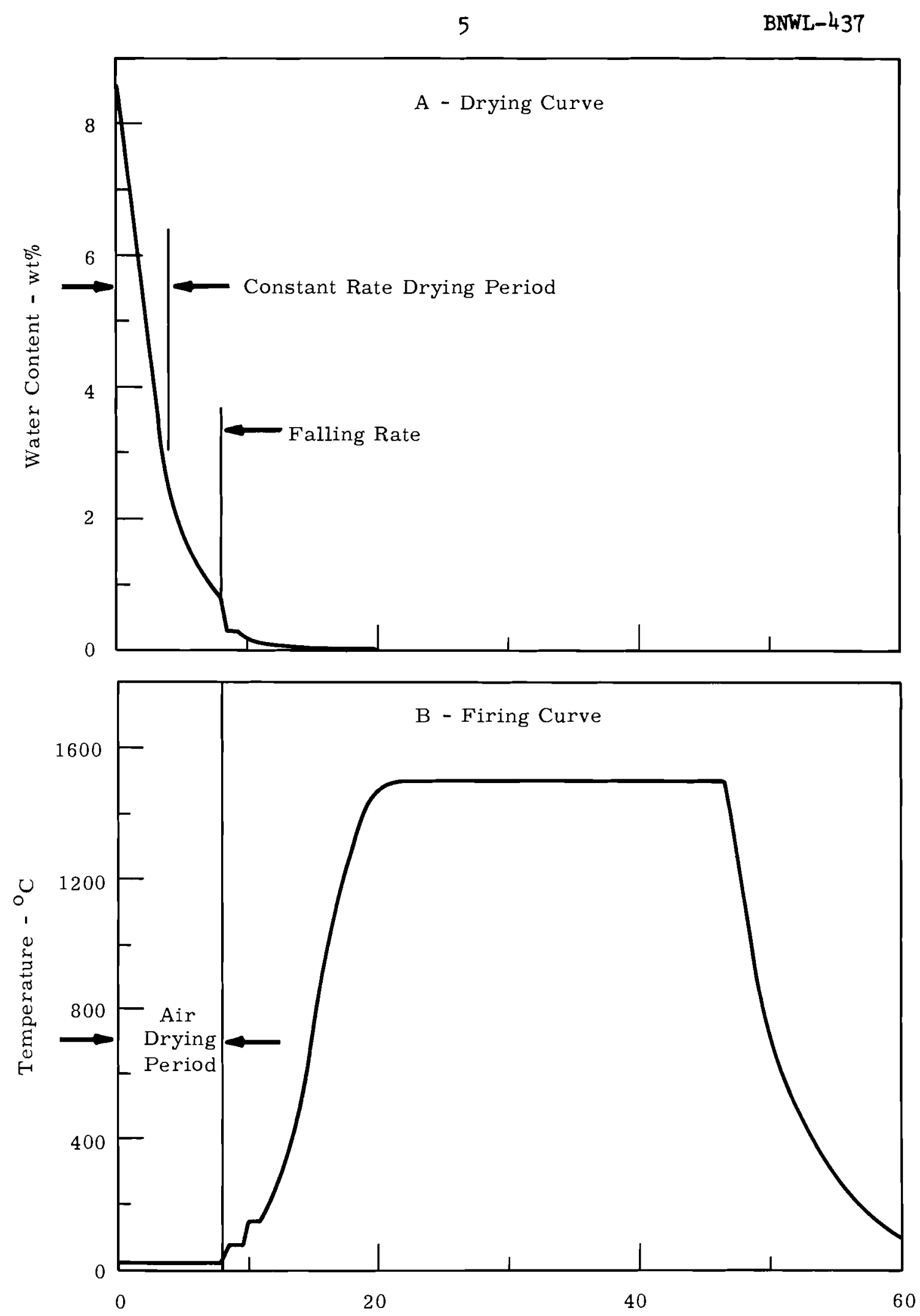

Time - hours

FIGURE 1 - Typical Drying and Firing Curves for Rare Earth Oxide Casts 
accurate measure of slip viscosity, however, due to oxide settiing; and the viscosity data given have an accuracy of no better than $\pm 20 \%$. Samarium and neodymium oxide slips appear to be non-Newtonian fluids of the dilatant class and their apparent viscosity increases with increasing shear rate. All viscosity data herein reported were obtained using a number 2 spindie and a speed of 20 RPM。

With samarium and neodymium sesquioxide sips a deflocculating agent is required to reduce slip viscosity to a usefui level. When a defloceulating agent such as Dexad 23 is used, a samarium sesquioxide slip containing as low as 11.5 wt.\% water is sufficientiy flid to be castable.

In preparing most of the rare earth oxide slips, 0.5 wt.\% Dexad 23 was used. Increased amounts of the deflocculating agent did not appear to reduce the viscosity appreeiably. It was found that a miliing time of about one hour was sufficient to produce a silp of minimum viscosity. With a "dilute" siip additional milling time did not appear to change the viscosity appreciably. With "concentrated" slips, however, the viscosity apparently increased substantiaily upon prolonged milling (See Table I)

\section{Table I}

Variation in Viscosity with Milling Time

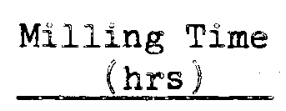

1

2

8
Viscosity (cps)

\begin{tabular}{cr}
\hline $40 \mathrm{wt} . \% \mathrm{H}_{2} \mathrm{O}$ & $16.6 \mathrm{wt}$ \\
$59.5 \mathrm{wt} . \% \mathrm{sm}_{2} \mathrm{O}_{3}$ & $\frac{82.9 \mathrm{wt} \%}{16}$ \\
16 & 82 \\
20 & 24 \\
20 & 246
\end{tabular}

The variations in silp wiscosity with water content for $\mathrm{Sm}_{2} \mathrm{O}_{3}$ slips are shown in Figure 2. The oxide used had been calcined at $1100^{\circ} \mathrm{C}$ prior to slip preparation. The calcination temperature appears to affect slip viscosity but not enough data was obtained to determine the exact relationship. Viscosity 


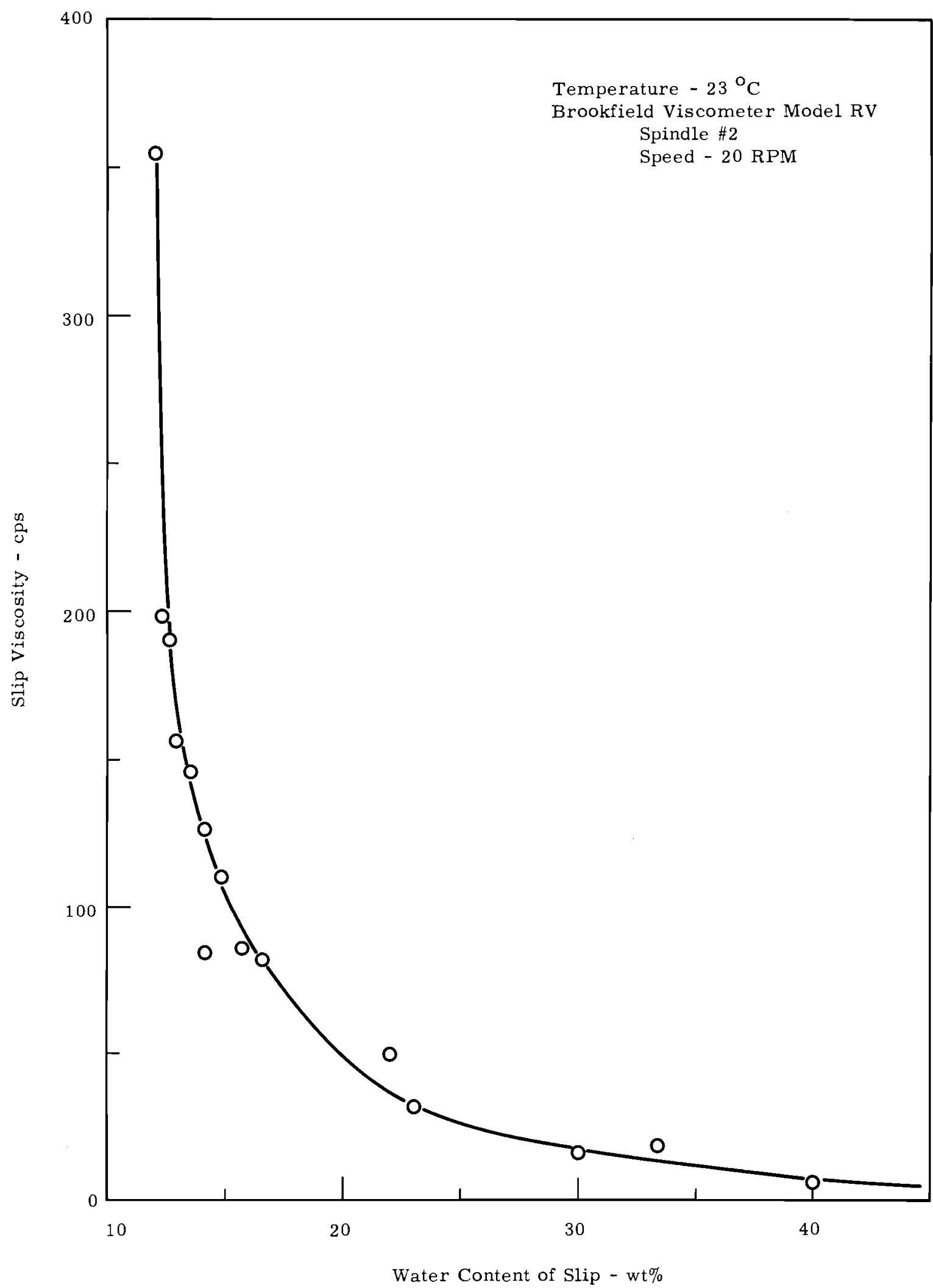

FIGURE 2 - Viscosity of $\mathrm{Sm}_{2} \mathrm{O}_{3}$ Slips as a Function of Water Content 
remadns fairiy low as the water content of the slip is reduced from $40 \mathrm{wt} \%$ to abont 20 wt. \%. At lower water contents, howeyer, the viscosity increases very rapidy and 2 was not found possible to prepare a fluid slip having a wate content of less than 11 wt.\%。

\section{SID Density}

The densities of $\mathrm{Sm}_{2} \mathrm{O}_{3}$ and $\mathrm{Na}_{2} \mathrm{O}_{3}$ slips depend primarily on the water content of the slips and on the temperature at which the oxide is ealcined prior to lse. The effect of water content is shown in Figure 3 for oxides calcined at $1100^{\circ} \mathrm{C}$. The variation in silp density with oxide calcination temperature was onily partially evaluated and the results available are shown in Table Ir.

\section{Tabie II}

Variation in Slip Density with Oxide Caicination Temperature

\begin{tabular}{|c|c|c|c|}
\hline Oxide & $\begin{array}{l}\text { Calcination } \\
\text { Temp. }{ }^{\circ} \mathrm{C}\end{array}$ & $\begin{array}{c}\text { Water content } \\
\text { Wt. \% } \\
\end{array}$ & $\begin{array}{r}\text { SIip Den } \\
\text { gm/ce }\end{array}$ \\
\hline Lindsay $\mathrm{Sm}_{2} \mathrm{O}_{3} *$ & Unknown & 22.3 & 2.95 \\
\hline $\mathrm{Sm}_{2} \mathrm{O}_{3}$ & 1100 & $22 \cdot 3$ & 3.02 \\
\hline $\mathrm{Sm}_{2} \mathrm{O}_{3}$ & 1500 & 22.0 & 3.51 \\
\hline
\end{tabular}

* Samarium sesquioxide as received from Linasay Chemical has a cubic structure whereas oxide ealcined at $800^{\circ} \mathrm{C}$ and above has a monocinic structure.

\section{CASTING CHARACTERISTICS}

In the casting operation the importent considerations are:

- Transfer of the silp from the ball mill to the mold.

Remoral of the cast rrom the mold.

The green density of the cast shape.

The first two factors are important in as par as they effect the radiation exposure of the personnel. The third is important because of its effect on the firing characteristics of the cast shapes. 


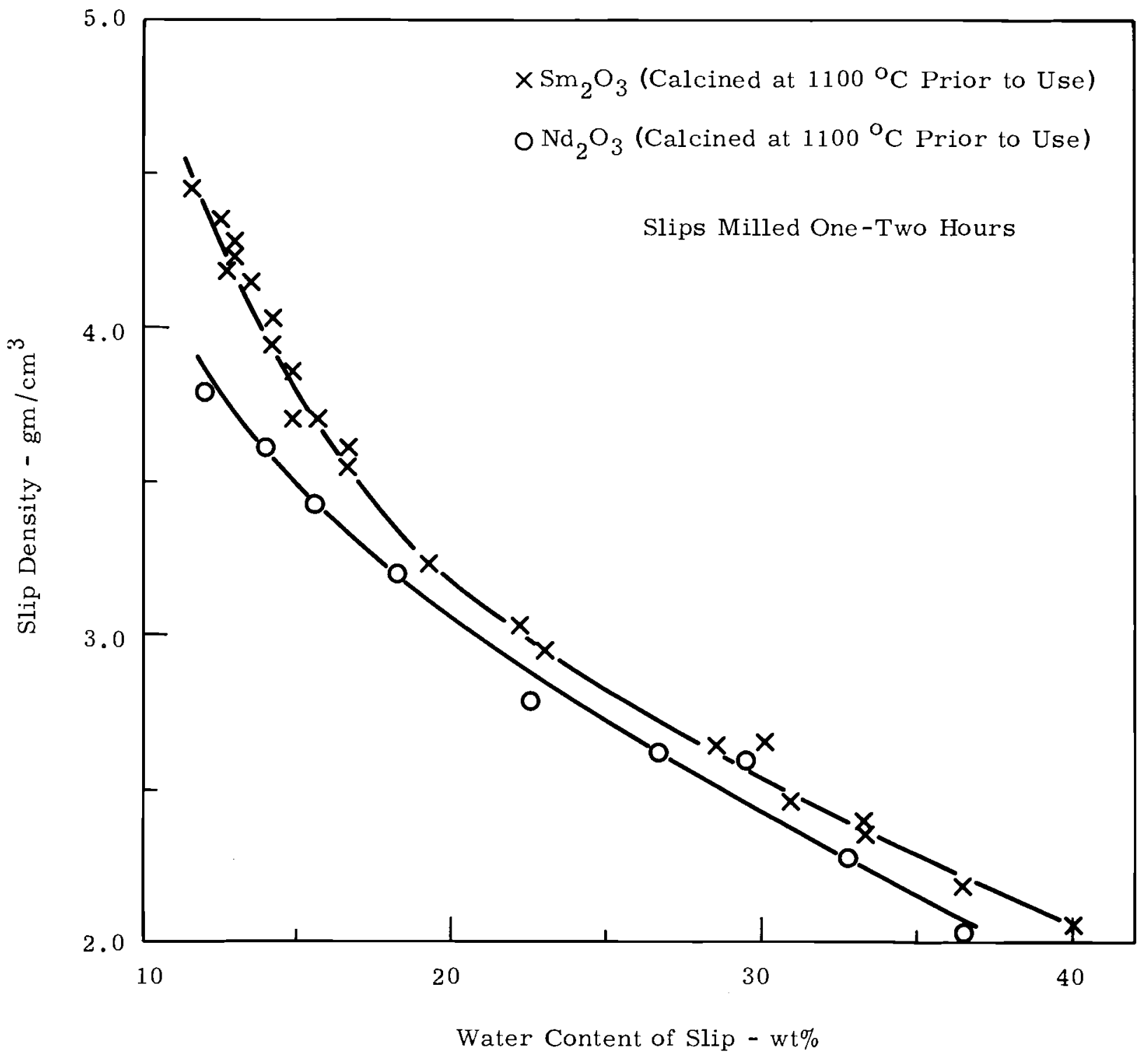

FIGURE 3 - Slip Density as a Function of Water Content for $\mathrm{Sm}_{2} \mathrm{O}_{3}$ and $\mathrm{Nd}_{2} \mathrm{O}_{3}$ Slips 


\section{Cast Preparation}

As previously stated, samarium and neodymium oxide slips containing as Ilttle as 11.5 th.\% water can be suceessully cast in plaster molds. The water content (and thus the viseosity) of the silp, however, has a pronounced effect on the ease of the casting operation. High viscosity siips are difficult to remove from the mill and large amounts of the siips are always left behind. Low yiscosity silps are easily removed rom the mill but require longer casting times. The casting time is herein definea as the time required to fill the mold, but does not include the time required for the ast to set up so that it can be remowed from the mold. The data shows that the casting time varies with the water content of the slip assuming acnstant miliing time (Table III).

\section{Table III}

\section{Ef fect of Water Content on Casting Time}

$\begin{array}{lccc}\text { Oxide } & \begin{array}{c}\text { Miling Time } \\ \mathrm{Hr}\end{array} & \begin{array}{c}\text { Water Content } \\ \text { Wt. } \%\end{array} & \frac{\begin{array}{c}\text { Casting Time } \\ (\text { min })\end{array}}{\mathrm{Sm}_{2} \mathrm{O}_{3}} \\ & 1 & 12.5 & 5 \\ \mathrm{Sm}_{2} \mathrm{O}_{3} & 1 & 22.3 & 12 \\ \mathrm{Sm}_{2} \mathrm{O}_{3} & 1 & 40.0 & 20\end{array}$

In adition, it was found that the longer the casting time the ionger the setting up period before the cast could be removed from the mold. However, shapes made from low wiscosity sips, artex setting up, were much easier to remore from the molds than were those shapes prepared from high wistosity silps.

If the silps were milled for long periods or time ("two hours the casting times became excessive. For example, $\operatorname{Sm}_{2} \mathrm{O}_{3}$ slip containing $30 \%$ water, which had been milled for one hour" had a casing time of about 15 minutes to produce a one inch diameter by four inches long cyinder. A similar sip milled for elght hours had a casting tire of eight hours. $\mathrm{ANd}_{2} \mathrm{O}_{3}$ slip $\left(25.5 \% \mathrm{H}_{2} \mathrm{O}\right)$ milied for 60 how s had a casting time in excess $0 y^{4} 4$ hours. Therefore, the shortest miling time which gives a fuld shp is desired from a casting standpoint。 
The green strength of rare earth oxide casts is good and they can be handled readily without physieal damage. They are not as strong, however, as cold pressed pellets.

\section{Green Cast Density}

The green density of rare earth oxide casts depends primarily on the density of the silp (which in turn is dependent on the water content). This relationship is shown in Figure 4 for $\mathrm{Sm}_{2} \mathrm{O}_{3}$. The data given are for slips which were milled about one hour. If the slips are milled for longer periods of time ( 4 hours); the sifp density is not affected but the giteen cast density is greatly increased as shown by the following numbers (Table IV).

\section{Table IV}

Effect of Milling Time on Green Cast Density of $\mathrm{Sm}_{2} \mathrm{O}_{3}$

\begin{tabular}{|c|c|c|c|c|}
\hline $\begin{array}{l}\text { Water Content } \\
(\text { wt. } \%) \\
\end{array}$ & $\begin{array}{l}\begin{array}{c}\text { Milling Time } \\
\text { (Hrs。) }\end{array} \\
\end{array}$ & $\begin{array}{l}\text { Slip Density } \\
\mathrm{gm} / \mathrm{ce}\end{array}$ & Green & $\begin{array}{l}\text { Cast Density } \\
\mathrm{gm} / \mathrm{ce}\end{array}$ \\
\hline 22.3 & 2 & 3.02 & & 3.92 \\
\hline 22.2 & 8 & 3.02 & & 4.65 \\
\hline 30 & 1 & 2.68 & & 3.51 \\
\hline 30 & 8 & 2.65 & & 4.57 \\
\hline
\end{tabular}

The advantages of increasing seen density by additional miliing, however, are of set by the long casting times required.

The density of the green cast can also be increased by calcining the rare earth oxide at higher temperatures prior to slip preparation. The exact relationship has not been established but the following numbers indicate the over-all trend. 


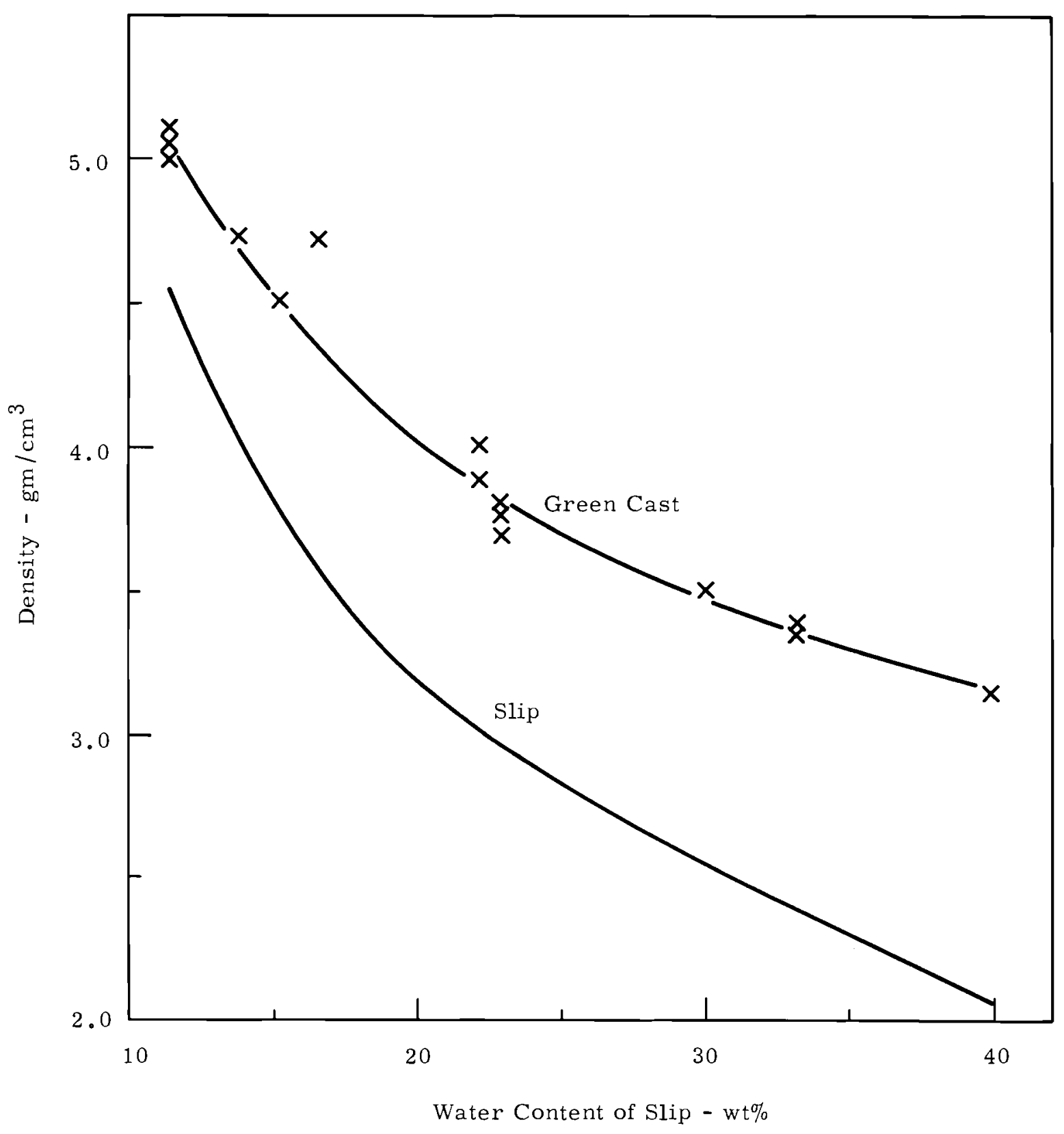

FIGURE 4 - Green Cast Density as a Function of Slip Composition for $\mathrm{Sm}_{2} \mathrm{O}_{3}$ 
Table V

Effect of Oxide Caloination Temperature on Green Cast Density

\begin{tabular}{|c|c|c|c|c|}
\hline Oxide & $\begin{array}{l}\text { Calcination } \\
\text { Temp., }{ }^{\circ} \mathrm{C} \\
\end{array}$ & $\begin{array}{l}\text { Water Content } \\
\text { of Slip - wt. } \%\end{array}$ & $\begin{array}{l}\text { Silp Density } \\
\mathrm{gm} / \mathrm{cc}\end{array}$ & $\begin{array}{c}\text { Green Cast } \\
\text { Density-gm/ce }\end{array}$ \\
\hline $\mathrm{Sm}_{2} \mathrm{O}_{3}$ & 1100 & 22.3 & 3.02 & 3.92 \\
\hline $\mathrm{Sm}_{2} \mathrm{O}_{3}$ & 1500 & 22.2 & 3.51 & 4.58 \\
\hline
\end{tabular}

\section{FIRING CHARACTERISTICS}

The objectives of the firing operation are to increase the physical strength and density of the cast shape. In adaition, uneven shrinkage and dimensional variations should be reduced to a minimum.

Density of Fired Shapes

For a given firing temperature and time, the density of the fired shape is related directly to the green density and, therefore, to the water content of the slip, the miling time, and the oxide calcination temperature. Figure 5 shows the variation in density of $\mathrm{Sm}_{2} \mathrm{O}_{3}$ fired shapes with the water content of the slip $\left(\mathrm{Sm}_{2} \mathrm{O}_{3}\right.$ ealeined at $1100^{\circ} \mathrm{C}$, milled $1-2$ hours and fired at 1300 or $\left.1500^{\circ} \mathrm{C}\right)$ It can be seen that a low water content and high slip density are required to give a high fired density:

When the slip cast shapes were fired at temperatures of $1100^{\circ} \mathrm{C}$ or less, no increase in density was achieved. Some sintering did occur but the devease in shape volumie was of set by the loss of moisture and the final density of the fired shape was appiroximately the same as the initial green density. The variations in fired density with firing temperature for $\mathrm{Sm}_{2} \mathrm{O}_{3}$ shapes of varying green densities are summarized in Figure 6 . Figure 7 shows typical $\mathrm{Sm}_{2} \mathrm{O}_{3}$ shapes in the warious stages of the firing process.

Structural Stability

Slip-cast $\mathrm{Sm}_{2} \mathrm{O}_{3}$ and $\mathrm{Nd}_{2} \mathrm{O}_{3}$ shapes which had been fired at temperatures of $1100^{\circ} \mathrm{C}$ and above had good physical strength. However, those shapes which had low green densities always craked and spalled very badiy when al ir dried and fired. Most of the eracking occurred during the air drying period or when the shapes were heated from ambient to $200^{\circ} \mathrm{C}$. The most prevalent type of failure was the development of surface cracks and subsequent spaliation. 


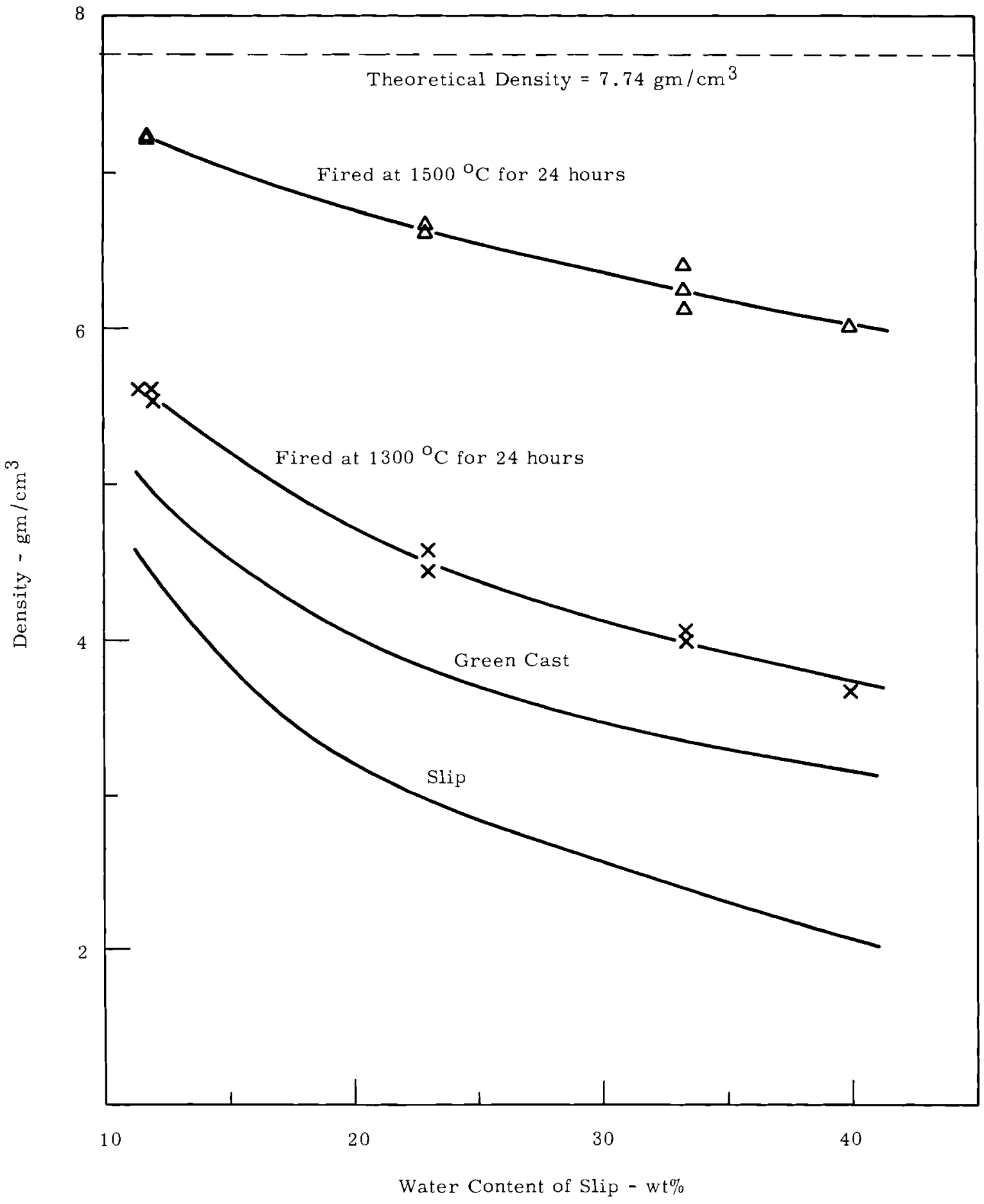

FIGURE 5 - Variation in Fired Density with Slip Composition for $\mathrm{Sm}_{2} \mathrm{O}_{3}$ 


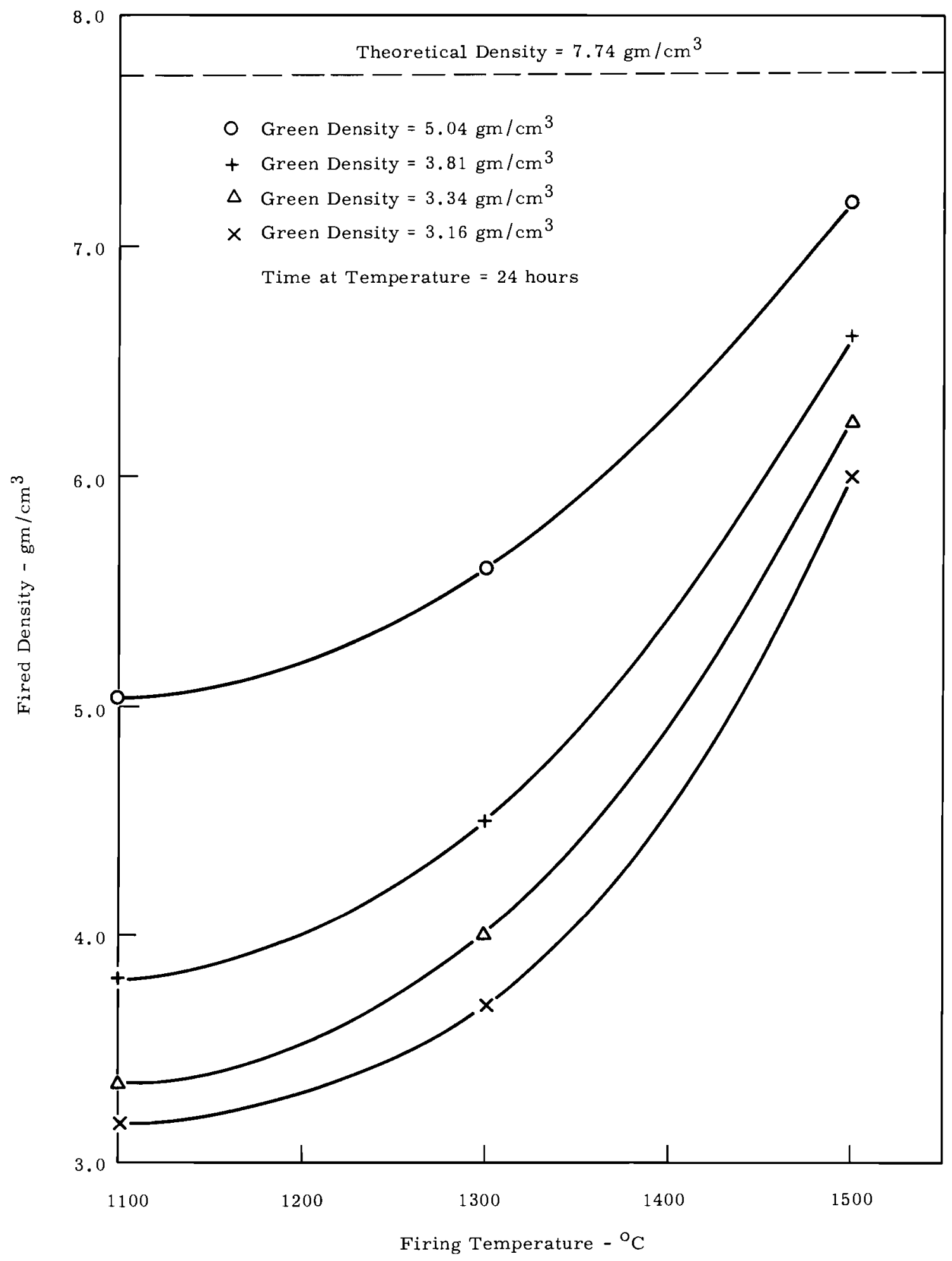

FIGURE 6 - Variation in Fired Density of $\mathrm{Sm}_{2} \mathrm{O}_{3}$ with Firing Temperature 


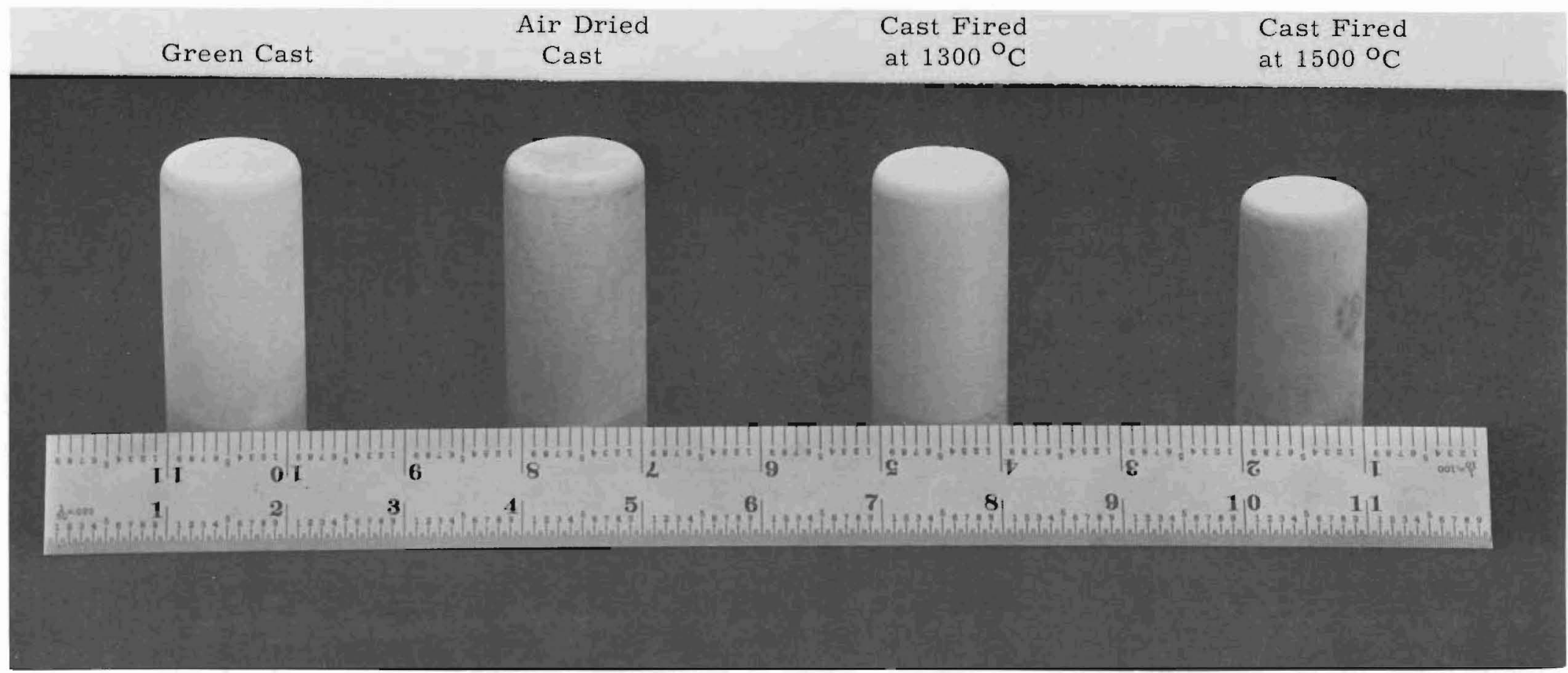

FIGURE 7 - Various Stages in the Firing of $\mathrm{Sm}_{2} \mathrm{O}_{3}$ Shapes 
High density green shapes, on the other hand, could be aried and fired without craking if the heating and cooling rates were carefuliy controlied in the range of $20-500^{\circ} \mathrm{C}$. Even with high density green shapes some sirface cracks developed if the drying and heating rates were too great. Normally, about a 6-8 hour drying period was required to prevent surface cracks from developing.

Typical flawed $\mathrm{Sm}_{2} \mathrm{O}_{3}$ shapes are shown in Figure 8 . Shape 8-A shows surface eracks as a result of too rapid a drying rate, 8-B shows some spaliation and a major crack due to too rapid a cooling rate; 8-C shows the effect of uneven heating; and 8-D shows a small amount of surface blistering and spallation. Figure 9 shows a shape that has been correctly fired. No cracking or spalling has occurred, and the only flaws are some small voids at the surface.

Dimensional Control

Dimensional control of the slip cast shape is difficult to maintain during the fiting operation. Uneven shrinkage can give badly distorted shapes, while even under the most closely controlled conditions dimensional variations of 2-3\% are common. In addition, there is aiways some variation in shape dimensions due to one surface of the shape being in contact with the setter plate during the firing process. Figure 10 shows the dimensions of a typical rare earth oxide shape before and after firing (with optimum controi of the firing process). The shape has a slight taper to facilitate its removal from the mold. In firing, the small end was placed in contact with the setter plate to give a more uniform diameter.

\section{EVALUATION OF SLIP CASTING PROCESS}

In evaluating slip casting as a process for fabricating promethium sesquioxide into useable shapes, the evaluation must be based on the requirements set forth in Section 3, above. Since the experimental work was limited and not all the variables could be studied in detail, the over-all evaluation of the process that follows is based on qualitative impressions gained during the course of the work and in some cases have not been verified by experimental work。 


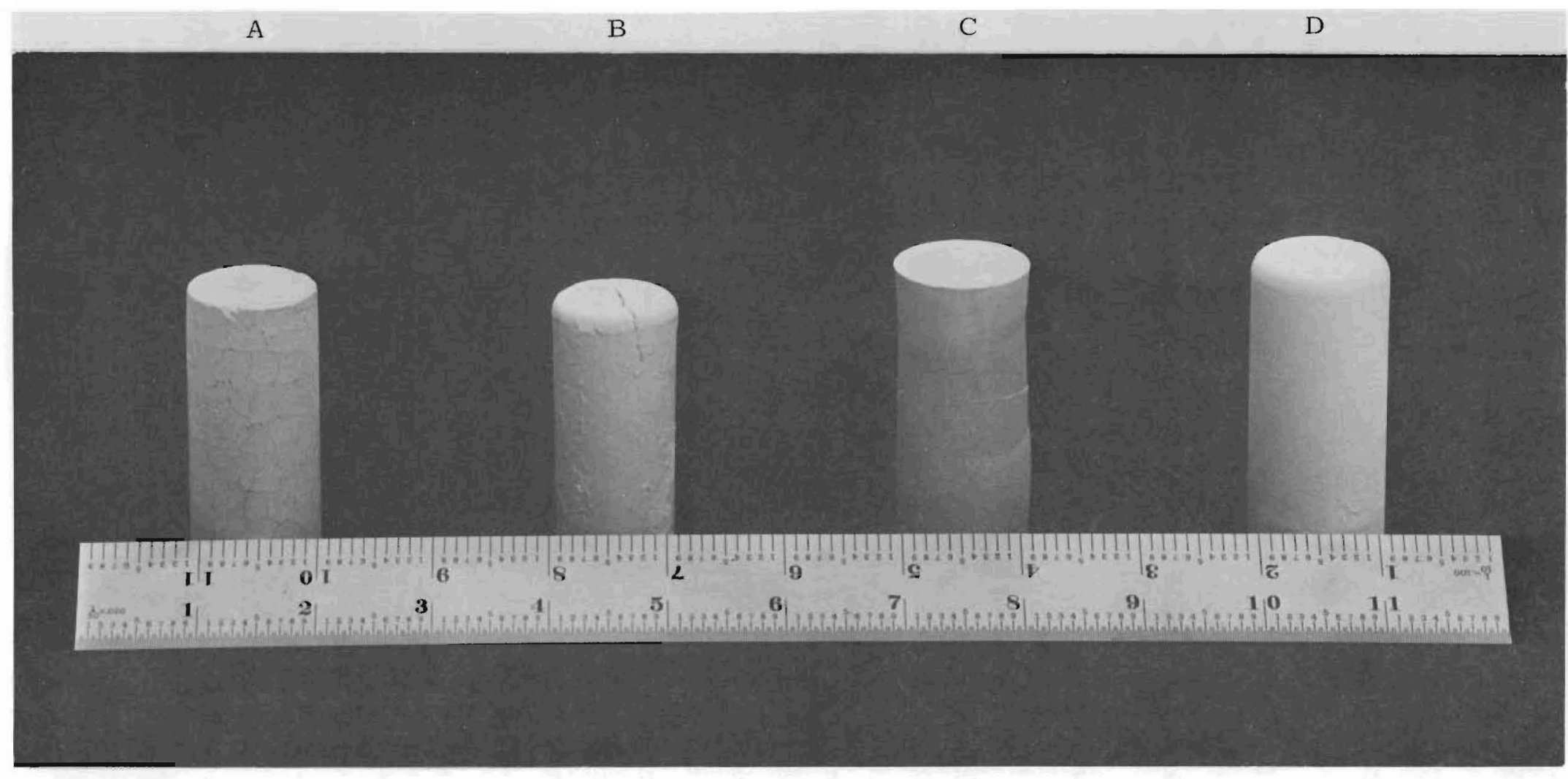

FIGURE 8 - Fired Shapes of $\mathrm{Sm}_{2} \mathrm{O}_{3}$ Showing Flaws due to Incorrect Firing 


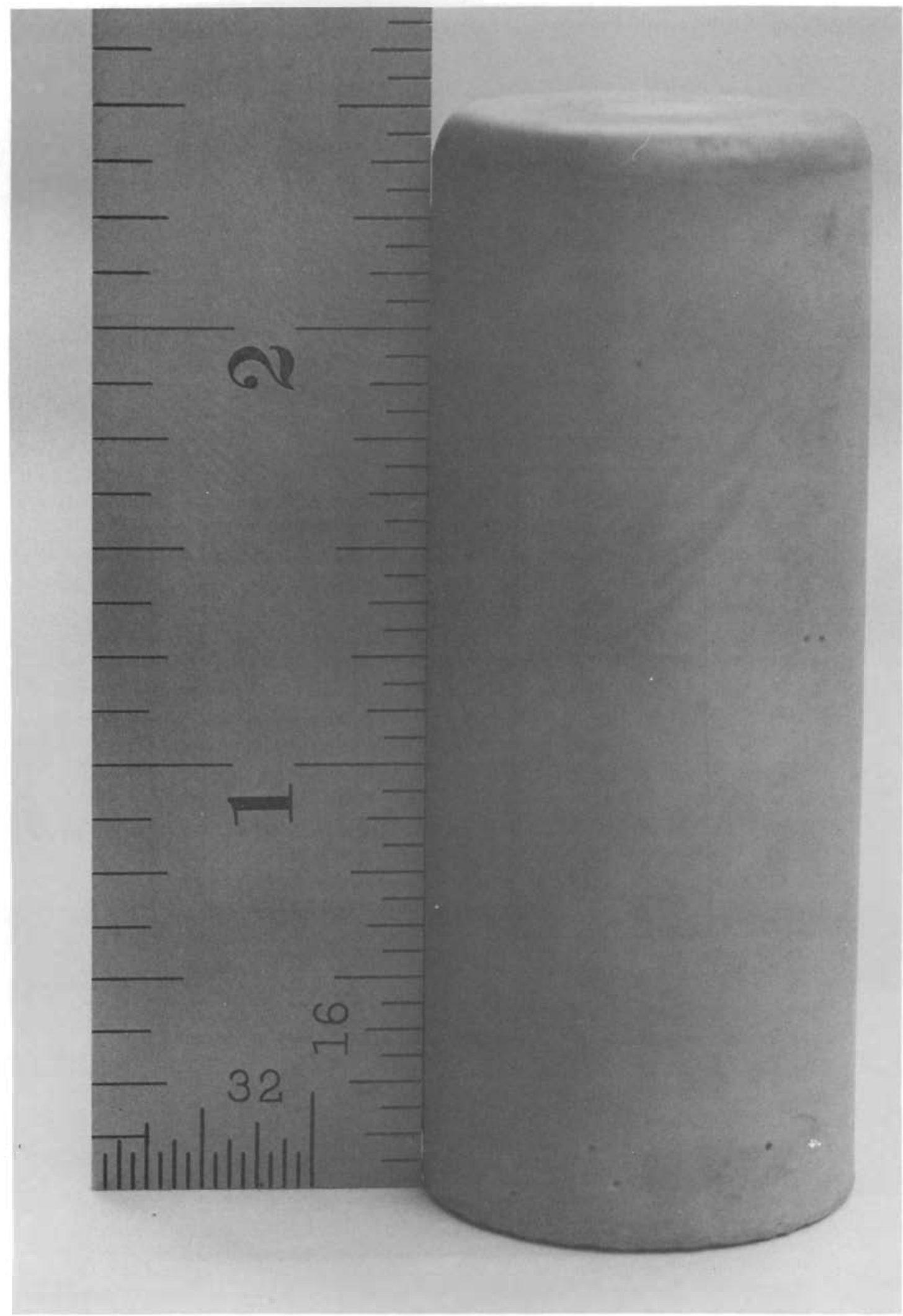

FIGURE 9 - Samarium Sesquioxide Shape Correctly Fired 

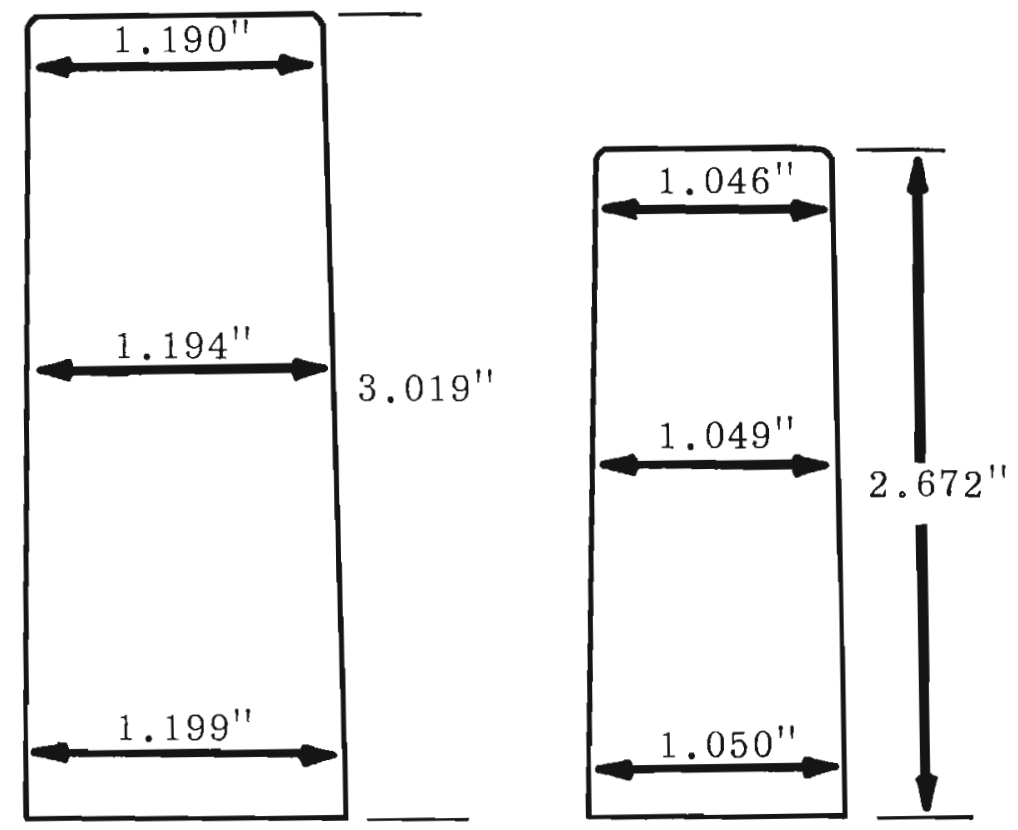
rensity. By selecting the proper casting and firing conditions, rare earth oxide casts of moderately high densities (90-95\% of theoretical) can be prepared quite readily. To produce shapes of higher densities will require firing temperature above $1500^{\circ} \mathrm{C}$. The rare earth oxide easts show a good uniformity of density, at least for the right circular cylinders that were prepared in this work.

Physical Strength. The unfired casts of $\mathrm{Nd}_{2} \mathrm{O}_{3}$ and $\mathrm{Sm}_{2} \mathrm{O}_{3}$ show good green strength and can be handled quite readily as long as reasonable care is taken. The air dried casts have strengths equivaient to the green casts, but the oxide at the surface has a powdery texure. The air dried shapes, therefore, should be handed as little as possible to prevent the loose powder from sloughing of $f^{\circ}$. The fired casts have excelient strength and texture. They can be handied readily and will stand a great deai of mechanical shock without damage. The above comments apply oniy to those casts which have been processed correctly, however, to prevent cracking and spalling. Fired casts which do have cracks show poor physiaal strength and iittie resistance to mechanical shock.

Dimensional Control. As in any silp casting process, dimensional control is very poor. Uneven shrinkage and warpage can be eliminated by careful firing, but even under the most carefuliy controlled conditions the reproducibility of the process is no better than $\pm 2-3 \%$ based on the physicai aimensions of the fired shapes.

Physical Operation. The physical requirements of the slip casting process are such that they can be performed in either a remotely operated facility or a gloved box. However, operation in a remote facility would require maripulators with a good lifting eapacity to handie items such as the ball milis.

Operator Exposure. If the process were to be carried out in a glove box, a fair amount of handing would be required. Since it would be aifficult to shield the various pieces of equipment, the operators would recelye substantial quantities of radiation to their hands. 
Physical Containment. Most of the work would be carried out with $\mathrm{Pm}_{2} \mathrm{O}_{3}$ in slurry form or as a compacted shape. There would be little handling of loose dry powder: thererore, the physical containment of the oxide would be relatively simple. However, in handing the siurries a number of items of equipment would buila up quantities of promethium which would result in a high background radiation lewe in a gloved box.

Based on the above factors, the following conclusions have been reached with regard to the use of slip aasting for fabricating promethium sesquioxide shapes.

1. If close dimensional control is required, silp casting is not a suitable process for compacting promethium sesquioxide. Where dimensional control is not critical, slip casting can ve used to prepare $\mathrm{Pm}_{2} \mathrm{O}_{3}$ shapes of moderately high density very readily.

2. Because of (a) the physical handling requirea and (b) the buildup of promethium in the process equipment; any production slip casting operation would have to be performed in a remoteiy operated facility。 For making a Iimited number of shapes, however, the work could probably be done in a glaved box without excessive operator exposure.

\section{ACKNOWLEDGEMENTS}

I wish to express my appreciation to Dr. R, $S$, Roseniels and $L_{0}$ Jo Adams of Isochem, Ine. for thely assistance in the initial phases of this program, and to $C_{0} y_{0}$ Mitcheil who assisted with muen of the experimental work. 


\section{DISTRIBUTION}

Number of Copies

326

Division of Technical Information Extension

1

Oak Ridge National Laboratory Donald BOX

1

Lawrence Radiation Laboratory James Hadiey

7

Isochem, Inco

S。J。Beard

J. S. Cochran

$O$. F。 Hill

$\mathrm{H}$. H。Hopkins, Jro

R. S. Rosenfels

P。W。Smith

R. E. Tomlinson

6

Richland Operations Office

N. T . Karagianes (3)

C. L. Robinson

R. K. Sharp

Technical Information Library

49

Battelie-Northwest
F。W.AIbaugh
J. M. Atwood
R。J.Baker
E。A。Berreth
D。 Wo Brite
I. I. Burger
R. E。 Burens
G。M。Dalen
D. $R$. deHalas
K. Drumheller
$H$. To Finiam (20)
$K$ 。 M。 Harmon
B. Mo Johnson, Jr。
I. J. Kixby

R。 L。 Moore

A. M. Platt

F。P. Roberts

$R$. $K$ 。 Robinson

C. A. Rohrmann

R。C.Smith

H。H。Van Tuyl

E。 E。Voiland

E. Jo Wheelwright

Technical Information Files (5)

Technical Publications (2) 